\title{
Synergetics and development processes in socio-economic systems: Search for effective modeling constructs
}

\author{
Natalya N. Lychkina \\ Associate Professor, Department of Information Systems and Technologies in Logistics \\ National Research University Higher School of Economics \\ Address: 20, Myasnitskaya Street, Moscow, 101000, Russian Federation \\ E-mail:nlychkina@hse.ru
}

\begin{abstract}
This paper explores the genesis of socio-economic processes of strategic development of social transformations in a transition economy. The author studies the system patterns and structural and dynamic aspects of developing socio-economic systems, defining the need for appropriate modeling methods. Restrictive features of traditional mathematical modeling are analyzed.

Synergetics is applied as a theoretical and methodological fundamental of research and modeling of developing socio-economic systems. Modeling social behavior, individual choice, various forms of social interaction and self-organization processes are recognized to be significant aspects. Searching for methods of model description is based on carrying out interdisciplinary research in the field of economic and social sciences, using modern paradigms (system dynamics, agent-based computer simulation) and simulation technologies and analysis of their possibilities in the study of the dynamic aspects of the development processes in socio-economic systems. A general concept of simulation of developing socio-economic systems based on the principles of stratification is proposed: the micro-level reproduces individual decisions of social and economic agents, as well as the collective organizational forms; and the macro-level describes processes of evolution. The interpretation of the interactions between socioeconomic configurations is based on analysis of causal dependencies and dynamic manifestations of the interpenetration of phenomena occurring in different strata of the social system. It offers methods of combining composite system-dynamic and agent-based models, allowing us to investigate the dynamics of socio-economic processes by a cyclical interaction of processes of individual and group behavior of economic and social agents at the micro level with the basic processes of socio-economic system at the macro level.

The basic directions of development of technologies of simulation in procedures and strategic decision support systems are defined as follows: a computer dynamic scenario analysis based on a generalized simulation model of the control object; a model of balance of interests in the procedures of coordination of scenarios and interests of the participants of the process of social design; a stratified description of the model set with the use of ontologies; methods of parameterization of models of socio-economic systems and the specifications of agents.
\end{abstract}

Key words: strategic development, socio-economic systems, synergetics, simulation modeling, system dynamics, agent-based modeling, stratification.

Citation: Lychkina N.N. (2016) Synergetics and development processes in socio-economic systems:

Search for effective modeling constructs. Business Informatics, no. 1 (35), pp. 66-79.

DOI: 10.17323/1998-0663.2016.1.66.79. 


\section{Introduction}

$\mathrm{F}$ ormation of the foundations of strategic planning in the Russian Federation in practice sets the task of creating and implementing long-term development strategy at all levels of public administration: federal, regional, sectoral and corporative. The multiplicity of possible scenarios of such development requires solution of the tasks of analysis of such scenarios and analysis of potential trends of socio-economic system development, taking into consideration numerous factors that influence these processes, including the internal potential and the processes of self-organization in socio-economic systems (SES), the synthesis of effective development scenarios, analysis of attainability of the goals set and evaluation of the risks of their unattainability.

What are the specific features of the current situation? Most economists define Russia's economy as an economy undergoing transformations in the process of shifting to market relations: a country with a market being formed and a society moving from a command economy to a market-oriented economy. This results in the determination of development of liberal democratic forms in socio-political life of the society and, first of all, establishment of social institutions, an active role of personality and citizens' freedom of will. Change of the economic model and the social structure connected with it defines the current process as a transitional process connected with reformation of the main spheres of economy and society, the step-by-step introduction of new institutional forms and mechanisms of economic, financial and other kinds, which in general corresponds to transitional processes in economic and social life of society.

We cannot solve this task without studying the genesis of socio-economic phenomena and development processes in SES which are characteristic for transition economies, and the ways of modeling them. In a transitional economy, SES shifts from its previous condition to a qualitatively new one. Potential trends of such development depend not only on the measures taken, administrative resolutions and the type of structural reforms but also on a large number of internal and external factors, stochastic, chaotic and turbulent occurrences in external environment, on the capability of the SES itself to be self-organized and self-reproduced.

\section{Economic paradigms shift - computer simulation of paradigms shift}

The modeling methods that were functioning efficiently not so long ago - in the socialist economy planning, under static conditions - are not suitable for studying transition processes in the economy under conditions of social transformations that are typical for the present socio-economic situation.

Why are system analysis and economic cybernetics and their traditional apparatus of economic and mathematical modeling not enough for the modeling of socioeconomic processes in case of a transition economy and social transformations?

Recent publications stating that the processes which can be seen in society and in socio-economic phenomena are somewhat similar to the processes being researched by such a branch of systemological sciences as synergetics [1] resemble philosophical discussions about the possibility of implementing theoretical synergetics postulates in the field of socio-economic research into current events in Russia. Are there any new practical approaches, constructive model designs that are useful for studying socio-economic processes in the new economic situation? Yes, there are. However, due to the inertness of academic schools researchers still try to approach developing systems with the old mathematical apparatus. Rebuilding the system of society results in the need for reconstruction of the models that are used to describe it. The goal of this research is to demonstrate model designs and approaches based on using modern paradigms and technological solutions in the field of simulation modeling of socio-economic processes and social forecasting that allow us to study complex dynamic occurrences in the development of socio-economic systems which are characteristic for the real economic situation in Russia.

Traditional econometric modeling methods do not allow us to describe the processes of development and self-organization in SES. Hypotheses stating that the tendencies we have observed in the past, on retrospective data, should be continued in the future are not valid under the conditions of transition processes. Statistical data on socio-economic processes, even in case of representative samples, trend models, cannot be the basis for describing a unique, sole and specific trend, as proven by the experience of the societal system in its development process. Statistics and the experience of other countries do not help draw the details of possible SES trends when they are applied to particular socio-economic conditions and historical periods. The state of the system in the future (according to J.Forrester) depends not only on its current state but also on the entire past history, i.e. on the way that has led the system to such a state. However, an econometric model helps to reveal and explain the relationship between particular factors, explain certain stable phenomena - but does not form the whole picture. 
Attempts to reveal and give a timeframe for cycles in the SES life cycle do not explain the mechanisms of changes and structural reformation taking place in complex systems. They can teach us to "follow the tides" but not to manage them. Management should be performed at bifurcation points - but modern management science does not provide methodological recommendations on this issue. Changing the political and socio-economic mechanisms of development predetermines the establishment of new principles and conditions for organizing SES development management.

Actuarial evaluations are perplexed by the stability of financial systems of the state but problems are located in other units of the socio-economic system.

Economists create models of economic systems in which they use Western instruments with the hypotheses of the "perfect market", the so-called models of general economic equilibrium where the equilibrium in markets is reached instantly, not taking time into consideration. Their macroeconomic reference points do not include such important aspects of societal systems as social behavior, population, its motivation, individual choice and activity; these reference points are shown aggregated, as rational economic agents (e.g., households that maximize the utility function). The rational choice theory has been criticized for a long time in economic and management research in respect to organizational systems. The issues of bounded rationality of the decision-maker are thoroughly studied in H.Simon's works [2].

The social sciences try to understand the way people act, the way they interact. Traditional quantitative tools of sociologic research reveal superficial occurrences in society but they cannot help reveal system patterns in the process of societal development. Social behavior emerging at the micro level can lead to global changes in the societal system. In order to study it, we need extensive interdisciplinary research and communications in a broad specter of the humanities on society, economy and psychology.

\section{Genesis of the processes of strategic development of SES.}

\section{Synergetics of socio-economic systems and dynamic} aspects of modeling the developing SES

Strategic management is the systemic development of a complex system with time [3] which requires analysis of structural changes and dynamic aspects of its development. Strategic management stipulates the transition of the system from its current state to a desirable goal state in a rather long period of time. The term 'development' here means the movement of the system in a phase space, the change of the system states stipulated by external and internal causes, in the process of which new structures and systems can originate. To determine the character of this movement, the path of the system's advancement with time, which depends on the current state and the potential of a system, on external impact and the character of managerial decisions - this is the main task of analysis and dynamic modeling. The dynamic model of a system is nothing other than a time-ordered sequence of its states, the last of which is equivalent to the goal of the system [4]. It is important to remember that in case of a developing system the dynamic model should describe the structural changes, and also the mechanisms of origination of new forms and structures that emerge in the process of its development.

\section{Structural and dynamic complexity of SES, specific aspects of developing SES}

We shall consider some aspects of researching and modeling socio-economic systems and processes that are stipulated by structural and dynamic complexity of this particular class of simulation objects and shall determine specific aspects of developing SES:

$\checkmark$ structural complexity. Non-uniform structure, structural changes;

$\checkmark$ numerous cause and effect relations, direct and inverse relations within the system structure. As a rule, cause and effect are separated in time and space;

$\checkmark$ a large number of influencing factors (multiple-factor character). Non-linear character of occurrences.

$\checkmark$ dynamic complexity (delays, different process speeds, oscillating processes) complicates the interpretation of system behavior (interaction);

$\checkmark$ management via inverse relations, adaptability;

$\checkmark$ dependency on history: the state of a system in the future depends not only on its previous state but on its entire past history as well [5];

$\checkmark$ developing SES. Analysis and choice of a development path. The rules of decision making (development scenarios) can also change with time; the points of application of managerial efforts can change with time;

$\checkmark$ counter-intuitivity of complex SES [5, 6], limited opportunities for expert evaluation;

$\downarrow$ conflicts between long-term and short-term decisions;

$\checkmark$ behavioral aspects connected with an entity of particular elements of a complex system;

$\checkmark$ uncertainty, including uncertainty in determination of development goals. Random and chaotic factors, stochastic process. Uncertainty of the environmental influ- 
ence on the system. Chaos. Uncertainty of the development of the system with time;

$\downarrow$ evolution and transitional processes. Instability, phase transitions in the system;

$\downarrow$ self-organization, dynamic behavior can emerge spontaneously, depending on the internal structure and impact from the external environment. Generation of the internal organization of SES through self-organization (and self-reproduction).

Understanding all the processes of economic development and societal development is more complex than equilibrium $[9,10]$. SES can be both in equilibrium state and demonstrate specific dynamic behavior in the development process. If the change of the external environment exceeds a particular limit, the system can become unstable and start moving to another phase or form of internal relations. Stability is replaced by instability and phase transition. There are several phases in the process of SES development. Under the influence of exogenous factors of stochastic and turbulent character with unidentified dynamics the system loses its stable state, its structure is being changed. Under the influence of impulses produced by the transforming structure, self-organization processes are started at the micro level; these processes can lead to origination of new forms and organizations and, thereby, the development processes and the transition to a new state - in such systems are initiated. Its further stability or instability depends on a large number of factors. The most important case is the phase transition, i.e. bifurcation of the most probable ways and trends of the SES sectors being examined. Transition through bifurcation points can be accompanied by negative trends, degradation, system destruction, protracted stay in chaotic state. The further way of development of a complex SES depends on correct management. It is known that management should be performed at bifurcation points - but modern management science does not provide methodological recommendations on this kind of management.

What if we test the managerial decisions we make with the help of computer models? However, the established practice of making managerial decisions is to make decisions "here and now", without being responsible for the long-term consequences of such decisions. Classification of modeling approaches on the basis of the object and subject principle (some models study the object of management, analyze its functioning process; other models (which study operations) create, synthesize optimal management and managerial decisions) only complicate the procedures of making long-term forecasts. To look into the distant future, to form a strategic vision - such a task can be solved better with the help of qualitative judgments and philosophic generalizations than with the help of scrupulous quantitative analysis. Uncertainty in forming the goals of strategic development, in making forecasts in a complex environment impedes social planning and development of scenarios of the future, even in case of massive expertise and foresight technologies. Of course, we can increase the amount of experts' responsibility but their capabilities are limited. It is necessary to help experts, to provide them with computer tools, some kind of "computer foreteller" that could help them evaluate and compare development alternatives, evaluate long-term consequences of the decisions being made. The modern theoretical and methodological basis of system modeling and high-tech solutions of simulation modeling can solve this task which is overwhelming for the expert community, and can also help create consolidated (for different expert groups, ensuring the conciliation of the interests in the triad: civil society, state, business) scenarios of movement to the desired future. The main thing is to include the expert and analytical community, the persons responsible for developing managerial decisions and all the interested parties (civil society, business) in the interactive process of social modeling of the future.

\section{Let's touch upon the issue of categories and essence of simulation modeling. It's like nothing on earth...}

From the standpoint of history, simulation modeling (SM) has had a relatively short development cycle in comparison with other types of modeling, starting from the 1960s [12]. Its establishment brings modeling theory to a qualitatively new level. As a result of the development of information technologies and computational methods (simulation as a type of modeling never existed without computers) new high technologies appeared in this sphere in the 1990s [13]. However, attempts to relate simulation to the modeling types which existed before its origination led to misunderstanding of the simulation method and restrained its application for solving practical problems.

Scientific and academic books abound in a large number of interpretations and incorrect definitions of simulation modeling (from a type of analog simulation to Monte Carlo method extensions). In order to understand why simulation modeling, in the author's opinion, can be used for describing processes in a developing SES, it is necessary to determine the categories and comprehend the character of simulation modeling [14].

We shall determine the following categories:

$\downarrow$ methodological foundation and theoretical and 
methodological fundamentals of simulation modeling;

$\checkmark$ simulation modeling method;

$\downarrow$ character and essence of simulation model;

$\checkmark$ simulation modeling technology;

$\checkmark$ simulation modeling paradigms (concepts);

$\checkmark$ simulation modeling tools;

$\uparrow$ computational methods used in simulation modeling.

The theoretical and methodological fundamentals of simulation modeling have been formed in the process of establishing a broad specter of system methods and system approaches, general systems theory, cybernetics and synergetics, adaptive regulation and automatic control, information theory and, finally, modeling theory - the system modeling technology [15], according to the definition given by the Russian classical scientific school. The methodological foundation of simulation modeling is applied system analysis which facilitates practical application on the basis of the system analysis methodology for the purpose of solving various complex problems in different fields. The central procedure of system analysis is the construction of a generalized model which reflects all the substantial factors and interconnections of a real system. Attempts to formulate a general theory of simulation modeling [16] have always led to particular generalizations that had some intersections with all the branches of systemology and a search for a universal methodology for describing processes in complex systems. In practice it has always been a way of solving particular applied problems. Military people were the first ones who used simulation in order to reduce the costs of expensive experiments. They were followed by engineers who needed reasoning for project decisions in complex technical systems; now it's the turn of economists, sociologists and managers - because in these fields experiments with real-world systems are wholly inadmissible.

The establishment of synergetics and its variations studying objects of different character $[1,10]$, in comparison with the complex of systemological sciences, its predecessors, has updated dynamic systems analysis, focusing it on research of specific structural and dynamic changes in complex systems, studying the transition processes from chaos to order and back, including the processes of self-organization and self- disorganization in open, non-linear environments of different character. Though cybernetics and automatic control theory, as comprehensive management sciences, included negative inverse relations, they generally studied the issues of ensuring system stability. Moreover, synergetics is a theory of non-stationary, developing systems for which the influence of fluctuation becomes a reason for sub- stantial changes in the system behavior. The synergetic and information approach can be regarded as a further development of the system approach [11] but it provides new opportunities for studying processes and events in society not only in stationary state (homeostasis) but also allows us to analyze the processes of development and disharmony in complex systems.

The simulation modeling method is an experimental method of research into a complex system on the basis of its counterpart - a computer model directly replicating structural and dynamic properties of the object being modeled, which combines the specific features of the experimental approach and the specific conditions of using computer technologies. This definition emphasizes two important characteristics of simulation modeling (and it is also the source of non-scientific and incorrectly translated name of this method in Russian):

$\diamond$ marked isomorphism of structural and dynamic characteristics of the object and its computer counterpart;

$\diamond$ experimental character of simulation (in order to obtain data about the object being modeled, we need to carry out a goal-directed computing experiment on a simulation model; its content and method are stipulated by research tasks).

"Direct replication of structural and dynamic properties of the object" in this definition means that at the stage of creation of a simulation model system analysts perform structural analysis and dynamic description of basic interaction processes, and it also means that the simulation model created always visualizes, allows us to observe (in the form of computer-generated imagery, flow charts, diagrams etc.) the structure and dynamics (state, behavior, development path) of the object being modeled. This is a substantial advantage of simulation modeling in comparison with other models and methods.

Simulation models belong to the class of dynamic and stochastic models, but determination of this classification characteristic does not allow us to understand their specificity, in comparison with other types of mathematical modeling. Simulation models - logical and mathematical ones - form a subclass of algorithm models. Construction of a simulation model implies combined use of mathematical, heuristic, expert methods and other methods of analysis without substantial deformation of structures, elements, processes, relations of order and connections of modeling objects [16].

Inherently a simulation model is always a dynamic model and it reflects the transition of a system from its particular state (state variables is the most important class of variables in simulation models) to another 
state under the impact of a multitude of influencing factors; simulation modeling is a dynamic representation of changes of the system states with the lapse of time, a kind of a "dynamic portrait" of the system being modeled. We can state that this is a specific feature of simulation modeling, characteristic only for this class of algorithm models, which allows us to describe the processes of functioning and development in complex systems. The interaction of elements in simulation modeling of complex systems is defined with the help of special operational rules, agreements in the field of a large number of abstract elements forming one or another class of systems; numerous parallel processes are synchronized with the help of special mechanisms of model time advancement which are tied to a unified simulated time scale.

The simulation model is always a stochastic model and it allows us to research complex systems under the influence of numerous stochastic factors, random events, risks and other occurrences determined with the help of stochastic variables. Due to this characteristic and the aforementioned properties, running a simulation model is always a kind of random implementation of the modeling processes. In order to obtain statistically significant results, we have to repeat simulation model running many times. This feature often leads to misinterpretations and drawing analogies to the Monte Carlo method. But this illusion vanishes immediately when it comes to the structural and dynamic complexity of the system being modeled (a large number of heterogeneous elements and processes running with different speeds in different units of a complex system).

It is known that simulation modeling is used in case there is a lack of theoretical knowledge or formal mathematical models, or if classic issue definition in the research field leads to computational problems [12]. Simulation modeling allows us to surmount the limitations of axiomatics of any mathematical method [16].

Simulation modeling technology as a method of creating computer models has some specific features connected with the importance of the stage of problem structuring and conceptualization on the basis of the system reasoning of the experts on this issue (the simulation model is created on the basis of the structured verbal (conceptual) description of the system being modeled). The process of determining a generalized structure of the SES being modeled is an informal procedure performed by system analysts and experts specializing in this issue, in the environment of expert revisions and extensive interdisciplinary communications. It allows us to describe the process of developing system-dynamic models of complex systems as a method of structuring the experts' knowledge of this issue and refer the models of this class to the sphere of cognitive analytics and knowledge management technologies which are connected with some areas of artificial intelligence.

Simulation modeling paradigms are the different ways of conceptualizing the object being modeled on the basis of the methods of determination and implementation of basic abstract elements and model variables and the rules of their interaction, and also the ways of model time advancement. The most popular paradigms that are already included in the modern instruments of simulation modeling: the process approach, system dynamics, agent-based modeling and simulation. Let us take a brief look at the content of these paradigms because it is important for the further reasoning.

Process-oriented simulation (or discrete event simulation DES) has become a tool for engineering and projecting not only technical systems but also business processes, logistics, transport systems and many other types of systems. This approach was initially offered by J.Gordon as a way of movement of dynamic systems in networks, queuing systems. It is characterized by a high level of discreteness, extraction of features of all the entities, description of a set of random events implemented in such systems. Initially it was oriented to the description of parallel and interacting processes; today it is a universal method of process description which allows us to study, measure time and cost of these processes, reveal bottlenecks, synchronize and optimize processes in complex systems.

System dynamics (SD) is a method of describing nonlinear dynamic systems with inverse relations which is based on flow stratification or representation of the system being modeled as an aggregate of interacting flows of different character. This method was offered by the American scientist J.Forrester [5-7]. There is no discreteness here for representation of particular processes - the system is modeled at a high level of aggregation. According to the fundamental concepts of system dynamics, the key element in describing the system dynamics is its structure represented as interacting flows, and also the interaction of inverse relation contours in its structure. Emphasis is made on the managerial aspect and on understanding the system behavior but not on obtaining precise quantitative estimates. The language of system flow charts and the specialized graphic technique for structuring the dynamic objects being modeled make this approach a very expressive and efficient tool for system analysis procedures - decomposition and subsequent composition (synthesis) of a complex dynamic system on the basis of cause-effect analysis and the principles of inverse information relations. 
Agent-based modeling and simulation (ABMS) [18] emerged not so long ago as a kind of a specific branch in a broad specter of sciences dedicated to artificial intelligence and computer technologies. Presently it draws its conceptual view and existence philosophy in social sciences, behavioral economics, management, cognitive psychology etc. Agent-based models represent the real world as separately specified active elements which are called agents; these elements interact between themselves and with their environment. The activity of the agents is expressed in their capability to form individual behavior. The behavior of a complex system emerges as the result of interaction of agents in which they perform their behavior; this allows us to observe and study the patterns and features characteristic for the system in general.

There are also other paradigms of simulation modeling; the process of searching for a universal methodology of structuring dynamic systems is not finished yet. Presently the simulation modeling paradigms are the different views of the description processes and events occurring in complex systems. In practice, structuring of the object being modeled is performed in the context of the paradigm being applied.

Modern simulation systems implementing the modeling algorithm that reproduces the functioning of a complex system in which a particular concept of structuring is fixed are high-tech tools of system modeling. The merits of computer sciences and the development of information technologies and their intensive use in business applications and socio-economic research have made the simulation modeling tools available not only for experienced IT specialists but also for managers, administrators, data domain specialists and decision-makers, thanks to the user-friendly visual interfaces, tools for forming models with the help of chart representation and other representation types. Simulation modeling tools provided additional opportunities in the area of carrying out experimental research, visualization and interpretation of the results of simulation modeling etc. [13, 14]. Simulation modeling technologies and tools continue developing due to reference models and library solutions for different application fields. Promising lines of development of simulation modeling technologies and tools are connected with the search for universal schemes and concepts of structuring, stratification support, scenario approach development. At present, particular trends of these high-tech solutions are aimed at transferring simulation modeling to those users who are meant to create and use them - decision-makers and experts on specific issues!
In spite of the aforementioned user-friendly character of modern simulation systems, according to their computational character they are extremely complex analytical tools which allow us to perform quantitative analysis of SES functioning (in contrast to structure-functional modeling and cognitive analysis) with the help of various computational methods (time advancement mechanisms and scheduling for dealing with temporal collisions, numerical methods, random action generators and mechanisms of statistical information gathering and processing by objects and time marks of the system being modeled, and many more), and a number of analytical applications (statistical procedures, optimization methods etc.) that support the goal-directed computing experiment on a simulation model.

The stages of source data gathering and processing, the procedures of dynamic models parameterization, specification of processes and agents require analysts to be competent in different areas of applied mathematics. Simulation model creation is always a well-organized project, and the process of its development requires collaboration of experts on specific issues, system analysts, IT specialists and programmers, mathematicians and project managers. Procedures of organizational interaction between project participants are established. Modern consulting has a lack of experience in managing such projects [19]; this is one of the influential factors holding back the implementation of SM-based solutions in the practice of public and corporative administration, social projecting of the future, in the infrastructure of information, expert and analytical activities in the sphere of strategic planning and scenario analysis, foresight technologies support.

\section{General concept of simulation of developing socio-economic systems}

Modeling of a complex SES has a problem of stratification of SES structural layers and interpretation of interaction between the layers. Different layers of a complex system are characterized by different degrees of organization and the character of dynamic processes in different strata of such a system. We can conventionally determine particular strata in SES description and examine the cyclical transitions between socio-economic configurations:

$\checkmark$ the micro level - the main focus of research is the individual solutions of economic and social agents;

$\checkmark$ the meso level - the collective organizational forms (and social groups in the society system);

$\checkmark$ the macro level - the processes of SES evolution and development. 
Internal dynamics and the processes occurring at the micro level and meso level of SES have a significant impact on the behavior of the entire system and determine the path (trajectory) of further development of the system. At the macro level new system characteristics of society emerge. On the contrary, the processes at the macro level form the environment for the lives of many individuals at the micro level, where they implement their decisions depending on the current socio-economic situation. Approaches to SES stratification based on structural approaches need to be supplemented with interpretations of interactions between downward and upward strata of the socio-economic system that describe the cause-effect relations and dynamic manifestations of the interpenetration of phenomena occurring in different strata of the socio-economic system. Consistency in the consideration of the societal system and socioeconomic system is enhanced by the cyclical character of descending and ascending interaction between the main strata of the simulated system, highlighting aspects of such interaction in systems of various types. It turned out that a verbal description of such interaction is not enough to reveal the dynamic aspects of manifestation of such interaction between different strata of the socioeconomic system.

Let us consider the general approach to the creation of simulation models which describe such phenomena in socio-economic systems. The simulated model of a society system should connect the micro level at which individuals make decisions and take actions, and the macro level which describes the state, the basic structure and the development of such a system. All the model variables are constantly changing during the long-term period under the impact of external and internal factors, in the environment of transforming system structures and socio-economic system characteristics.

In the process of creation of a generalized simulation model of a socio-economic object, system dynamics models and methods are used. At the macro level model designs are produced by means of the aggregated system-dynamic models describing the main elements and processes of development of a societal system: population, economy, production and social infrastructure, environment and other factors of social life. In terms of non-linear dynamics, formation of this model stratum is an attempt to present the fundamental equation of a system, with the main phase variables describing evolution, dynamics of socio-economic system in aggregated form. However, Markov hypothesis does not allow us to set up formalisms and mechanisms of development in such systems, due to the complex cause-effect relations, the aim to describe the entire retrospective of such development and its influence on current and future states of a developing SES.

The methodology of system dynamics allows us to simulate dynamic processes at a high level of aggregation; it is based on the idea of functioning of a dynamic system as an aggregate of flows (of cash, people etc.). There are two sections in the general structure chart of system dynamics models: flow chart and information chart. The latter joins together numerous managerial decisions and scenarios tested in a simulated model. System-dynamic simulations of SES are the flow type models: resources (natural, human, financial etc.) are being depleted, resources are being replenished, and they can be described as a network of heterogeneous flows. The state of SES is described by specific variables - "levels" (the number of people of different categories, production facilities, financial resources etc.), and it defines the accumulations forming within a system. External influences and managerial decisions determine the rate (of reproduction, resource consuming, dynamics) of the system being modeled. On the basis of processing of the experts' knowledge all the factors functioning in the particular system and cause-effect relations between them are determined. System-dynamic model is aimed at conceptualization and structuring of problems, understanding of the occurring processes, revealing of the sense, - system dynamics methods are close to the reasoning of strategic managers. The societal systems modeling process is performed in the environment of broad interdisciplinary communications, participation of specialists in different fields in the expert revision procedures. The methods of ontological modeling and cognitive analytics are efficient tools of such work which help reveal implicit knowledge in the expertise procedures.

System dynamics offers a paradigm, a methodology and a technological approach which differ from the traditional ones. It allows us to analyze complex dynamics, non-stationary socio-economic systems being in a process of transition, a structural change, with uncertain and dynamic external environment. Generalized description of a SES presented at the macro level should be based on the terms of correspondence of its internal structure, functional organization (through the relation of its constituent elements, key units of development) and its development dynamics. The SES structure, being changed and transformed under the impact of internal impulses, influences the dynamics (behavior) of SES and its development processes. The causes of destabilization and changeover to other dynamic modes are located in interacting dynamic processes occurring in different SES 
units and at different rates. It is the possible paths and the route of long-term evolution of a SES that are the main subjects of analysis in system-dynamic simulated models. The major task of administration of a developing system is to manage the process of development through controlling time, timely revealing moments and twists in development, branching of dynamic processes and moving through bifurcation points and "points of no return", performing analysis of trajectories of the SES sectors being studied, identifying the points of application of managerial efforts.Model designs of system dynamics are based on reliable econometric estimates which are used for bringing the system flow charts of the model to well-defined quantitative proportions at the stage of its parameterization. Parameterization of dynamic models of SES is performed on the basis of mathematical models according to the results of monitoring socio-economic processes, with the use of the intellectual data analysis method, the results of examination and the results of sociologic studies.

Time is a special variable in the scenario task of managing a dynamic system as well. Development of such scenarios, taking into consideration their dimension (numerous control parameters), distribution in time (character and time of application of managerial impacts which perform the changeover of system from its current state to the desired goal state in a rather long period of time), should be based on the information about the possible paths of SES development and analysis of the impact of managerial decisions. Methods and technologies of generation of possible SES management scenarios require the active participation of experts and decision-makers in procedures of development of such scenarios according to the results of possible behavior trajectories analysis, which are performed with the use of the simulation model of the object of management. Strategic management analytics is set up in the form of procedures of dynamic computer-based scenario analysis using a generalized simulation model of the object of management. The scenario approach allows experts to form possible development scenarios or SES movement paths based on the information about the SES state and structure as well as action programs (plans), and to analyze them with the help of a simulation model.

At the level of micro processes description, aggregated system-dynamic models of SES are supplemented with agent-based models and also with models describing the interaction of a multitude of social groups.

The human factor in both its individual and collective manifestations is essential in the study of socio-economic processes. The active elements of the economic and social system are people, individuals. They are a rather complex system as well. An individual can have certain rationality if he is acting in a market, but he never possesses complete information. He competes or collaborates, changes his behavior under the influence of changes in his institutional environment and the strategies being implemented by other participants. He accumulates experience and knowledge, enriches his mental models on the basis of which he makes decisions. The operations of agents in the market are predetermined by personal interest and individual behavior, institutional influence, relations which are formed between the agent and the institutional environment. There are a number of sciences - first of all, organizational behavior, cognitive psychology, - proving that individuals are irrational, that they have mentality, emotionality; their actions are guided by their own rules, by implementation of their personal mental models. An important stimulus for the development of this branch was the replacement of the economic paradigm about the rational behavior of economic agents and the limitations of the mathematical apparatus supporting it by the concepts of bounded rationality of decision-makers, the development of the ideas of learning organization, the search for methods of describing intellectual economic and social agents' learning on the basis of experience.

An individual in a new societal system (civil society, liberal democratic forms) is not only an economic agent maximizing the utility function but a person who has freedom of choice and implements ways of individual behavior. His activity vector to a certain extent is characterized by "passionarity" which varies in different social groups. The composition of social groups is changeable. It is formed under the influence of general socio-economic trends taking place in the society. These mental models are formed not in the market but in the process of social agents' interaction with society, with other individuals, and they include not only the rational choice mechanisms but also the values formed in the process of social reproduction of value. Different individuals have a multitude of potential behavior types. Social sciences study the phenomena of origination of social and human capital which are formed in the process of social interaction and social reproduction. Therefore, at the micro level of SES we take into consideration the decisions and actions of individuals, motivation and behavior standards which are the characteristics of certain social groups.

The behavior of such a person, representative of the society, individual choice and his communications in society and economic life can be described using multi-agent simulation. Algorithmic constructions of such models can 
reproduce the individual behavior of such active agents at the micro level of the societal system. An agent can be an intellectual one (or not too intellectual), learning from his experience. Characteristics of an agent change with time. He alters his decisions under the influence of changes in his environment. He interacts, exchanges information with other participants of a socio-economic system. Groups and structural formations are set up. Changes in the organization of the socio-economic group itself arise. They influence the socio-economic environment in which the agent lives and makes his choice.

It is at the micro level where the processes of selforganization and self-reproduction are started. These processes determine stability and other dynamic manifestations in particular elements of a socio-economic system. It is possible to define a meso level at which we describe how people behave and interact; and where social groups forming as a result of such interaction are determined. Social behavior emerging at the micro level can lead to global changes in the societal system. The properties of a complex economic system at the macro level are formed as a result of agents' interaction at the micro level where their behavior is carried out. This allows us to observe and study patterns, properties and dynamics characteristic for the system in general.

The agent-based model allows us to investigate the individual behavior of different groups of agents, the specificity of their adaptation to the changing environment, and the way the processes of self-organization influence the evolution and development of the socio-economic system as a whole. The computational power of modern computers and the scaling technique allow us to produce a system with practically any level of complexity from a large number of interacting agents. The results of numerous sociological studies, theoretical knowledge in the social and economic sciences allow us to carry out clusterization, the specification of agents of the computer model. The key tasks of formation of this model level are connected with the procedures of identifying agents, their environment; the determination of the rules of their behavior (specification) and corresponding representation of the agents' interaction. The processes formed at the micro level allow us to determine classes and characteristics of agents, the rules of their decision-making, the character of interaction and information exchange between the system agents and with the external environment, etc.

Therefore, in the process of creation of an agent-based model we specify the individual logics of behavior of the process participants, and the tendencies, patterns and new properties of the entire system emerge as integral characteristics of behavior of a set of the agents that form the sys-

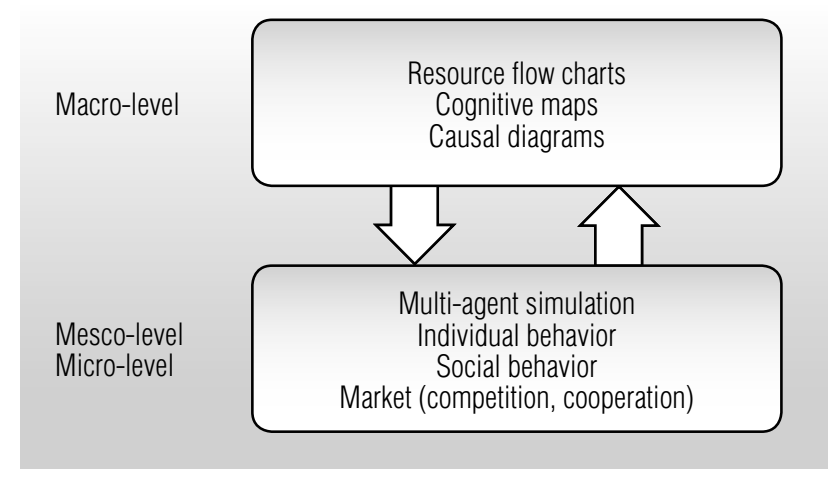

Fig. 1. The analysis of the dynamics of socio-economic processes through the cyclical interconnection between micro level and macro level in SES. Modern model design

tem, which can be revealed both at the meso level (group or social behavior, the formation of new structures) or directly at the macro level, in form of aggregated characteristics of SES. The emerging behavior and mutations in the process of functioning of an agent-based model transfer the signals to the macro level. The processes occurring at the macro level of a SES form the environment for existence of a multitude of such agents. Control actions at the macro level should be oriented to the manifestations in socio-economic processes that emerge at the micro level.

Thus, effective model designs of developing SES are created upon the principles of composite combination of system-dynamic simulation models and agent-based simulation models (Figure 1). Composite dynamic models of SES function on the basis of a united model and information frame which allows organizing the processes of information exchange and the mechanisms of interaction between the macro level and the micro level of the SES being modeled. SES at the macro level is an external environment in which social and economic agents carry out their individual behavior, and which to a large extent predetermines the rules of decision-making, experience and knowledge of the agents. In turn, the emerging social behavior starts the processes of self-organization, development or stagnation that define functioning and control of the SES in whole. Such an approach to creation of multi-model complexes on the basis of composite system-dynamic and agent-based simulation models allows us to study the dynamics and development of socioeconomic processes through the cyclical interconnection between micro level and macro level in a particular SES.

Model construction by the socio-economic systems are considered and applied by the author of this article in the constructionofdynamic modelsinthesocialsphere(health, education, housing, pension system), a regional system [20-26], organizational system, supply chain [27, 28]). 
The idea of creating composite and hierarchical models is not a new one, but in practice it leads to the problems of coordination of heterogeneous models and computational problems. They make it difficult to implement such models in informational and analytical practice. But it is no problem for the simulation modeling technology. The capacities of hierarchical modeling, support of stratification and evolution of the models are easily implemented with the help of solutions based on object-oriented programming and engineering, because the simulation model is a kind of a dynamic information system. Multiple sub-models of a generalized simulation model of an object function on the basis of a single research and information frame. They are united to form a single information and analytical infrastructure which makes it possible to encapsulate it into the structure of information and analytical center of any purpose.

\section{The infrastructure of information and analytical activity in strategic management}

The current level of development of information technologies allows us to create the infrastructure of cognitive centers and systems of support of strategic decision-making, where a simulation model is integrated with visual and mathematic models, ontology, monitoring systems, display panels, network expertise and other infrastructural components of the decision-making procedures ( Figure 2).
An SES simulation model is a system-forming link in the procedure of strategic decision-making in information and analytical centers (IAC), along with the monitoring system, data analysis, scenario generation methods, technologies of conducting scenario research and analyzing its results [20, 23, 29]. Strategic management analytics on the basis of IAC is set up in the form of procedures and landscape for conducting dynamic computer scenario analysis on the basis of a generalized computer model of the control object, supplemented with the methods of generation of possible SES development scenarios, expert analysis of the consequences of scenario implementation, methods and models of coordination of interests of the participants in the social planning process.

\section{Conclusion}

Created simulation models of SES are based on reliable econometric estimates in identification of socioeconomic processes and specification of social and economic agents. Analytical monitoring and situation analysis form an informational basis for describing the current state of a system-dynamic model, parameterization and specification of its elements (processes and agents). The procedures of expert revisions and expert cognitive analysis are used for stratification, ontology engineering of the socio-economic systems being modeled, formation of possible development scenarios tested in simulation models, and creation of the "balancing of interests" models.

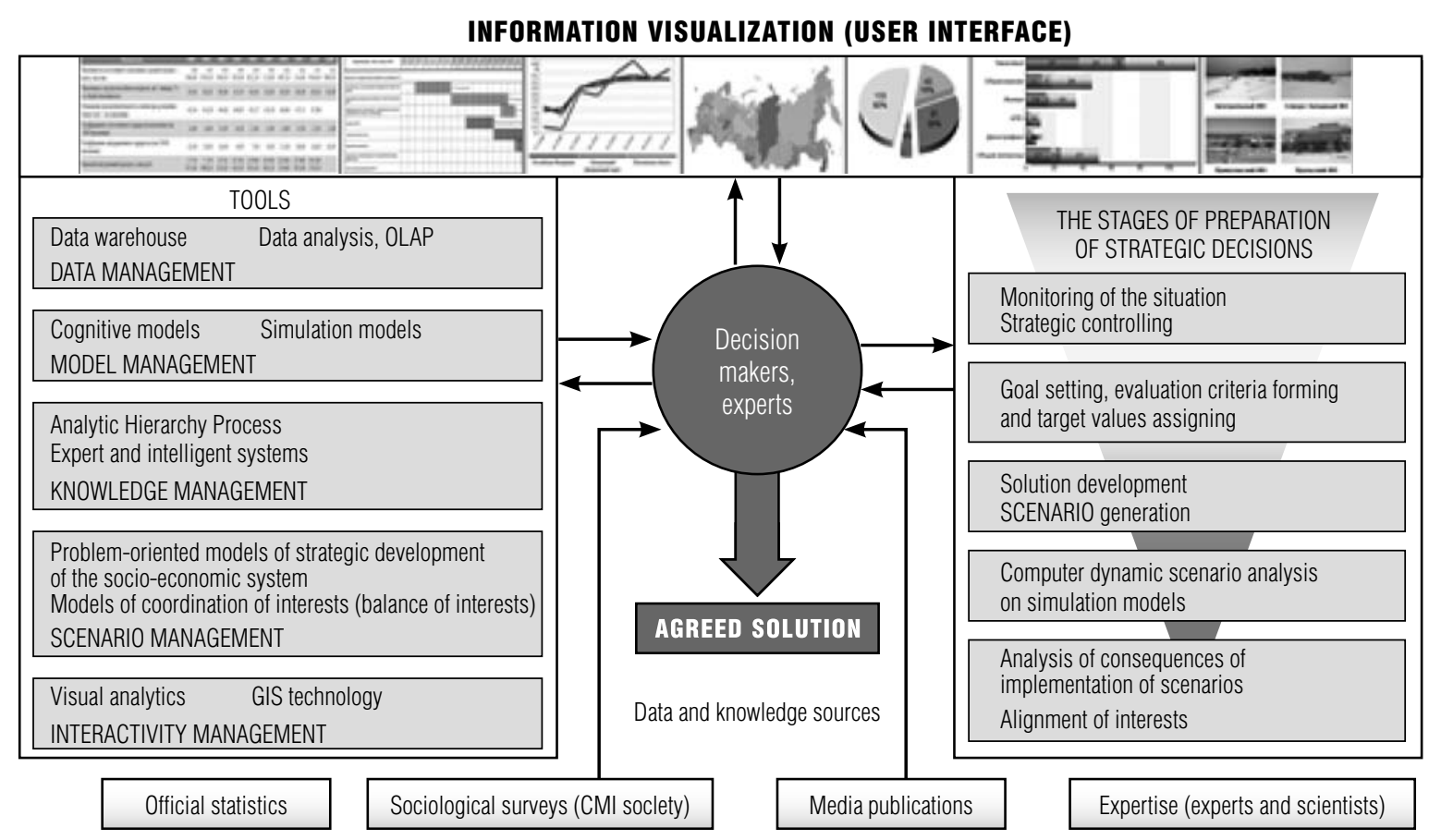

Fig. 2. The infrastructure of information and analytical activities in strategic decision support systems 
The scenario approach allows experts to form possible scenarios or trajectories of SES movement on the basis of the information about SES state and structure, and action programs (plans). They can analyze them with the help of a simulation model. An important aspect in forming strategic decisions is coordination and balancing of interests of all participants of this process: state, business, people. The discussions going on in the experts and analysts community, which is trying to offer a large number of scenarios of such development, create favorable conditions for forming a consolidated development scenario or a long-term "balancing of interests of all participants" on the basis of a simulation model.
Improvement of the technologies of system modeling and scenario planning on the basis of information and analytical centers in the framework of the tasks of strategic planning in public and corporative management requires improvement of the methods of conceptualization of systems being modeled and stratification of modeling complexes [30, 31] on the basis of ontologies; enhancement of the convergent component of the process of making agreed decisions on the basis of procedures of organization and expert revisions; creation of "balancing of interests" models with the use of network expertise technologies and expert assessment and visual modeling.

\section{References}

1. Haken H. (1980) Sinergetika [Synergetics]. Moscow: Mir (in Russian).

2. Simon H.A. (1995) Teoriya prinyatiya resheniy v ekonomicheskoy teorii o nauke i povedenii: Teoriya firmy [Theory of decision making in economics and behavioral science: Theory of the firm]. Saint Petersburg: School of Economics (in Russian).

3. Kleiner G.B. (2008) Strategiya predpriyatiya [The strategy of the company]. Moscow: Delo (in Russian).

4. Drogobytsky I.N. (2013) Sistemnyy analizv ekonomike [System analysis in economics]. Moscow: UNITY-DANA (in Russian).

5. Forrester J.W. (1969) Urban dynamics. Waltham, MA: Pegasus Communications.

6. Forrester J.W. (1971) World dynamics. Waltham, MA: Pegasus Communications.

7. Forrester J.W. (1961) Industrial dynamics. Waltham, MA: Pegasus Communications.

8. Meadows D.H., Meadows D.L., Randers J., Behrens III W.W. (1972) The limits to growth. New York: Universe Books.

9. Weidlich W. (2005) Sotsiodinamika. Sistemnyi podkhod k matematicheskomu modelirovaniyu v sotsial'nykh naukakh [Sociodynamics. A systematic approach to mathematical modeling in the social sciences]. Moscow: Editorial URSS (in Russian).

10. Zhang V.B. (1999) Sinergeticheskaya ekonomika. Vremya i peremeny v nelineynoy ekonomicheskoy teorii [Synergetic economy. Time and changes in the nonlinear economic theory]. Moscow: Mir (in Russian).

11. Prangishvili I.V. (2000) Sistemnyy podkhod i obshchesistemnye zakonomernosti. [System approach and system-wide patterns]. Moscow: SINTEG (in Russian).

12. Shannon R. (1978) Imitatsionnoe modelirovanie system: Iskusstvo i nauka [Simulation modeling of systems: Art and science]. Moscow: Mir (in Russian).

13. Lychkina N.N. (2001) Sovremennye tendentsii v imitatsionnom modelirovanii [Current trends in simulation]. University Bulletin, no. 1, pp. $135-141$.

14. Lychkina N.N. (2011) Imitatsionnoe modelirovanie ekonomicheskikh protsessov [Simulation modeling of economic processes]. Moscow: INFRA-M (in Russian).

15. Avramchuk E.F., Vavilov A.A., Emelyanov S.V., et al. (1988) Tekhnologiya sistemnogo modelirovaniya [Technology of system modeling]. Moscow: Mechanical Engineering; Berlin: Technician (in Russian).

16. Kobelev N.B., Polovnikov V.A., Devyatkov V.V. (2013) Imitatsionnoe modelirovanie [Simulation modeling]. Moscow: INFRA-M (in Russian).

17. Pavlovsky Yu.N. (2000) Imitatsionnye modeli i sistemy [Simulation models and systems]. Moscow: Fazis, CCAS (in Russian).

18. Makarov V.L., Bakhtizin A.R. (2013) Sotsial'noe modelirovanie - novyi komp'yuternyy proryv (agent-orientirovannye modeli) [Social simulation - a new computer breakthrough (agent-based models)]. Moscow: Economics (in Russian).

19. Lychkina N.N. (2009) Retrospektiva i perspektiva sistemnoi dinamiki. Analiz dinamiki razvitiya [Retrospective and perspective of system dynamics. Analysis of the dynamics of development]. Business Informatics, no. 3 (9), pp. 55-67 (in Russian).

20. Lychkina N.N. (2004) Komp'yuternoe modelirovanie sotsial'no-ekonomicheskogo razvitiya regionov v sistemakh podderzhki prinyatiya resheniy [Computer modeling of socio-economic development of regions in decision support systems]. Proceedings of the III International Conference "System Identification and Control Problems" (SICPRO'04). 28-30 January 2004, Moscow. Moscow: IPU RAS, pp. 1377-1402 (in Russian).

21. Lychkina N.N. (2012) Simulation modeling of socio-economic systems (system-dynamic models of the city and the agricultural area). Germany: LAP LAMBERT Academic Publishing (in Russian).

22. Lychkina N.N., Morozova Y.A. (2013) Dinamicheskoe modelirovanie protsessov razvitiya pensionnoy sistemy [Dynamic modeling of the pension system]. Applied Informatics, no. 3 (45), pp. 99-100 (in Russian).

23. Lychkina N.N., Shults D.N. (2009) Simulation modeling of regions' social and economic development in decision support systems. Proceedings of the 27th International Conference of the System Dynamics Society, 26-30 July 2009, Albuquerque, New Mexico, USA. Available at: http://www.systemdynamics.org/conferences/2009/proceed/papers/P1068.pdf (accessed 01 February 2016).

24. Lychkina N.N., Andrianov D.L., Morozova Y.A. (2011) Social sphere modeling based on system dynamics methods. Proceedings of the 29th International Conference of the System Dynamics Society, 24-28 July 2011, Washington, DC. Available at: http://www.systemdynamics.org/ conferences/2011/proceed/papers/P1211.pdf (accessed 01 February 2016).

25. Lychkina N.N., Morozova Y.A. (2014) Dynamic simulation of Pension system development processes. Proceedings of the 32nd International Conference of the System Dynamics Society. 20-24 July 2014, Delft, Netherlands. Available at: http://www.systemdynamics.org/conferences/2014/proceed/papers/P1180.pdf (accessed 01 February 2016).

26. Lychkina N.N., Morozova Y.A. (2015) Agent based modeling of pension system development processes. Proceedings of SAI Intelligent Systems Conference 2015 (IntelliSys 2015), 10-11 November 2015, London, UK, pp. 857-862. 
27. Lychkina N.N. (2007) Imitatsionnye modeli v protsedurakh i sistemakh podderzhki prinyatiya strategicheskikh resheniy na predpriyatiyah [Simulation models of processes and strategic decision support systems in the enterprise]. Business Informatics, no. 1, pp. 29-35 (in Russian).

28. Lychkina N.N. (2013) Innovatsionnye paradigmy imitatsionnogo modelirovaniya i ih primenenie v upravlencheskom konsaltinge, logistike i strategicheskom menedzhmente [Innovative paradigm of simulation and their application in management consulting, logistics and strategic management]. Logistics and Supply Chain Management, no. 5 (58), pp. 28-41 (in Russian).

29. Gorbunov A.R., Lychkina N.N. (2007) Problemy, aktual'nye zadachi i prioritety v sozdanii sistem podderzhki prinyatiya resheniy i primenenii imitatsionnogo modelirovaniya $\mathrm{v}$ sfere upravleniya i biznesa [Issues related with objectives and priorities of decision support systems and the application of simulation in the field of management and business]. Proceedings of the Third All-Russian Scientific-practical Conference on Simulation and its Application in Science and Industry "Simulation. Theory and Practice"(IMMOD 2007), 17-19 October 2007, Saint Petersburg, Russia, vol. 1, pp. 27-36 (in Russian).

30. Lychkina N.N., Morozova Y.A. (2012) Stratifikatsiya kak osnova inzhenerii tekhnologiy komp'yuternoy podderzhki prinyatiya gosudarstvennykh resheniy v pensionnoy sfere [Stratification as a basis of engineering of technology for computer support of decision-making in the pension field]. Business Informatics, no. 2 (20), pp. 20-28 (in Russian).

31. Idiatullin A.R., Lychkina N.N. (2011) Instrumental'naya realizatsiya arkhitekturnykh modeley predpriyatiya na osnove ontologiy [Instrumental implementation of enterprise architecture models based on ontologies]. Business Informatics, no. 5 (15), pp. 31-42 (in Russian).

\section{Синергетика и процессы развития в социально-экономических системах: Поиск эффективных модельных конструкций}

\section{Н.Н. Лычкина}

кандидат экономических наук, доиент кафедры информационных систем и технологий в логистике

Национальный исследовательский университет «Высшая школа экономики»

Адрес: 101000, г. Москва, ул. Мясницкая, д. 20

E-mail:nlychkina@hse.ru

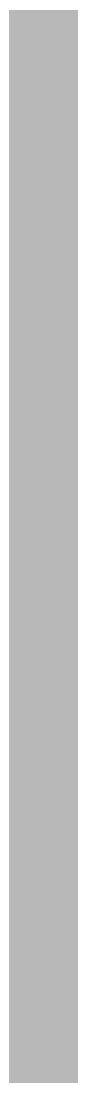

\section{Аннотация}

В работе исследуется генезис социально-экономических процессов стратегического развития, характерных для общественных трансформаций в условиях переходной экономики. Исследуются системные закономерности, структурные и динамические аспекты развивающихся социально-экономических систем, определяющие потребность в адекватных способах модельного описания, приводится анализ ограничительных возможностей традиционного аппарата математического моделирования.

В качестве теоретико-методологического базиса исследования и моделирования развивающихся социально-экономических систем применяется синергетика. Существенным аспектом признается отображение в моделях социального поведения и индивидуального выбора различных форм социального взаимодействия и процессов самоорганизации. Поиск способов модельного описания основывается на проведении междисциплинарного исследования в области экономических и социальных наук, применении современных парадигм (системная динамика, агентное компьютерное моделирование) и технологических решений имитационного моделирования, а также анализе их возможностей в исследовании динамических аспектов процессов развития в социально-экономических системах. Предложена общая концепция моделирования развивающихся социально-экономических систем на основе принципов стратификации: микро-уровень воспроизводит индивидуальные решения социальных и экономических агентов, а также коллективные организационные формы, макро-уровень процессы эволюции. Интерпретация взаимодействий между социо-экономическими конфигурациями осуществляется на основе анализа причинно-следственных зависимостей и динамических проявлений взаимопроникновения явлений, происходящих в различных стратах общественной системы. Предложены методы композитного сочетания системно-динамических и агентных имитационных моделей, позволяющие исследовать динамику социально-экономических процессов посредством циклической взаимосвязи процессов индивидуального и группового поведения экономических и социальных агентов на микроуровне с базовыми процессами развития и эволюции социально-экономической системы на макроуровне.

Обозначены основные направления совершенствования технологии имитационного моделирования в процедурах и системах поддержки принятия стратегических решений: динамический компьютерный сценарный анализ на основе обобщенной имитационной модели объекта управления, модели баланса 
интересов в процедурах согласования сценариев и интересов участников процесса социального проектирования, стратифицированное описание модельного комплекса с применением онтологий, методы параметризации динамических моделей социально-экономических систем и спецификации агентов.

Ключевые слова: стратегическое развитие, социально-экономические системы, синергетика, имитационное моделирование, системная динамика, агентное моделирование, стратификация.

Цитирование: Lychkina N.N. Synergetics and development processes in socio-economic systems: Search for effective modeling constructs // Business Informatics. 2016. No. 1 (35). P. 66-79. DOI: 10.17323/1998-0663.2016.1.66.79.

\section{Литература}

1. Хакен Г. Синергетика / Пер. с англ. М.: Мир, 1980.406 с

2. Саймон Г.А. Теория принятия решений в экономической теории о науке и поведении: Теория фирмы / Пер. с англ., под ред. В.М.Гальперина. СПб: Экономическая школа, 1995.

3. Клейнер Г.Б. Стратегия предприятия. М.: Дело, 2008. 568 с.

4. Дрогобыцкий И.Н. Системный анализ в экономике. М.: ЮНИТИ-ДАНА, 2013. 423 с.

5. Forrester J.W. Urban dynamics. Waltham, MA: Pegasus Communications, 1969. $285 \mathrm{p}$.

6. Forrester J.W. World dynamics. Waltham, MA: Pegasus Communications. 1971. 144 p.

7. Forrester J.W. Industrial dynamics. Waltham, MA: Pegasus Communications, $1961.464 \mathrm{p}$.

8. Meadows D.H., Meadows D.L., Randers J., William W. Behrens III W.W. The limits to growth. New York: Universe Books, 1972. 203 p.

9. Вайдлих В. Социодинамика. Системный подход к математическому моделированию в социальных науках / Пер. с англ., под ред. Ю.С.Попкова, А.Е.Семечкина. М.: Едиториал УРСС, 2005. 480 с.

10. Занг В.Б. Синергетическая экономика. Время и перемены в нелинейной экономической теории / Пер. с англ., под ред. В.В.Лебедева и В.Н.Разжевайкина. М.: Мир, 1999. 325 с.

11. Прангишвили И.В. Системный подход и общесистемные закономерности. М.: СИНТЕГ, 2000. 528 с.

12. Шеннон Р. Имитационное моделирование систем: Искусство и наука. М.: Мир. 1978. 418 с.

13. Лычкина Н.Н. Современные тенденции в имитационном моделировании // Вестник университета. 2001 №1. С.135-141 .

14. Лычкина Н.Н. Имитационное моделирование экономических процессов. М.: ИНФРА-М, 2011. 254 с.

15. Технология системного моделирования / Е.Ф.Аврамчук и [др.], под общ. ред. С.В.Емельянова. М.: Машиностроение; Берлин: Техник, 1988. $520 \mathrm{c}$

16. Кобелев Н.Б., Половников В.А., Девятков В.В. Имитационное моделирование: Учеб. пособие. М.: КУРС: ИНФРА-М, 2013. 368 с.

17. Павловский Ю.Н. Имитационные модели и системы. М.: ФАЗИС: ВЦ РАН, 2000. 134 с.

18. Макаров В.Л., Бахтизин А.Р. Социальное моделирование - новый компьютерный прорыв (агент-ориентированные модели). М.: Экономика, 2013. 225 с.

19. Лычкина Н.Н. Ретроспектива и перспектива системной динамики. Анализ динамики развития // Бизнес-информатика. 2009. № 3 (9). C. 55-67.

20. Лычкина Н.Н. Компьютерное моделирование социально-экономического развития регионов в системах поддержки принятия решений // Труды III Международной конференции «Идентификация систем и задачи управления» (SICPRO’04). 28-30 января 2004 г., Москва. М.: Институт проблем управления им. В.А.Трапезникова РАН, 2004. С. 1377-1402.

21. Лычкина Н.Н. Имитационное моделирование социально-экономических систем (Системно-динамические модели города и сельскохозяйственного региона). Germany: LAP LAMBERT Academic Publishing, 2012. $181 \mathrm{c}$.

22. Лычкина Н.Н., Морозова Ю.А. Динамическое моделирование процессов развития пенсионной системы // Прикладная информатика. 2013. № 3 (45). С. 99-110.

23. Lychkina N.N., Shults D.N. Simulation modeling of regions' social and economic development in decision support systems // Proceedings of the 27th International Conference of the System Dynamics Society, 26-30 July 2009, Albuquerque, New Mexico, USA. [Электронный pecypc]: http://www.systemdynamics.org/conferences/2009/proceed/papers/P1068.pdf (дата обращения 01.02.2016).

24. Lychkina N.N. Andrianov D.L., Morozova Y.A. Social sphere modeling based on system dynamics methods // Proceedings of the 29th International Conference of the System Dynamics Society, 24-28 July 2011, Washington, DC. [Электронный pecypc]: http://www.systemdynamics.org/conferences/2011/proceed/papers/P1211.pdf (дата обращения 01.02.2016).

25. Lychkina N., Morozova Y. Dynamic simulation of pension system development processes// Proceedings of the 32nd International Conference of the System Dynamics Society, 20-24 July 2014, Delft, Netherlands. [Электронный pecypc]: http://www.systemdynamics.org/ conferences/2014/proceed/papers/P1180.pdf (дата обращения 01.02.2016).

26. Lychkina N.N., Morozova Y.A. Agent based modeling of pension system development processes // Proceedings of SAI Intelligent Systems Conference 2015 (IntelliSys 2015), 10-11 November 2015, London, UK. P. 857-862.

27. Лычкина Н.Н. Имитационные модели в процедурах и системах поддержки принятия стратегических решений на предприятиях // Бизнес-информатика. 2007. № 1. С. 29-35.

28. Лычкина Н.Н. Инновационные парадигмы имитационного моделирования и их применение в управленческом консалтинге, логистике и стратегическом менеджменте// Логистика и управление цепями поставок. 2013. №5 (58). С. $28-41$.

29. Горбунов А.Р., Лычкина Н.Н. Проблемы, актуальные задачи и приоритеты в создании систем поддержки принятия решений и применении имитационного моделирования в сфере управления и бизнеса // Труды Всероссийской научно-практической конференции по имитационному моделированию и его применению в науке и промышленности «Имитационное моделирование. Теория и практика» (ИММОД-2007), 17-19 октября 2007, Санкт-Петербург. Т.1: Пленарные доклады. СПб: 2007. С. 27-36.

30. Лычкина Н.Н. Морозова Ю.А. Стратификация как основа инженерии технологий компьютерной поддержки принятия государственных решений в пенсионной сфере // Бизнес-информатика. 2012. № 2 (20). С. 20-28.

31. Идиатуллин А.Р., Лычкина Н.Н. Инструментальная реализация архитектурных моделей предприятия на основе онтологий // Бизнес-информатика. 2011. №5 (15). С. 31-42. 